\title{
Possibilities of care for serodiscordant couples for HIV who got pregnant
}

\author{
Possibilidades de cuidado ao casal sorodiscordante para o HIV que engravidou \\ Posibilidades de cuidados a la pareja serodiscordante al VIH durante el embarazo
}

\section{Tassiane Ferreira Langendorf', Ivis Emília de Oliveira Souza', Stela Maris de Mello Padoin", Cristiane Cardoso de Paula", Ana Beatriz Azevedo Queiroz', Maria Aparecida Vasconcelos Moura', Maria Carmen Simões Cardoso de Melo'III, Lúcia de Fatima da Silva ${ }^{\mathrm{IV}}$}

'Universidade Federal do Rio de Janeiro, Anna Nery School of Nursing, Postgraduate Program in Nursing. Rio de Janeiro, Brazil. "Universidade Federal de Santa Maria, Center of Health Sciences, Department of Nursing. Santa Maria, Rio Grande do Sul, Brazil.

II' Universidade Federal de Juiz de Fora, School of Nursing, Department of Applied Nursing. Juiz de Fora, Minas Gerais, Brazil.

Iv Universidade Estadual do Ceará, Department of Nursing. Fortaleza, Ceará, Brazil.

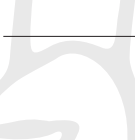

How to cite this article:

Langendorf TF, Souza IEO, Padoin SMM, Paula CC, Queiroz ABA, Moura MAV, et al. Possibilities of care for serodiscordant couples for HIV who got pregnant. Rev Bras Enferm [Internet]. 2017;70(6):1199-205.

DOI: http://dx.doi.org/10.1590/0034-7167-2016-0344

\section{Submission: 06-20-2016 Approval: 02-05-2017}

\begin{abstract}
Objective: Understanding the meaning of pregnancy for heterosexual couples facing serodiscordant situation for HIV, aiming at construction of care possibilities based on subjectivity. Method: Phenomenological research, theoretical-philosophical-methodological framework by Martin Heidegger. Research was conducted in a University Hospital in the countryside of Southern Brazil, from September 2013 to May 2014 through a phenomenological interview, with participation of eleven couples. Results: For the couples, pregnancy is part of life when they wish to have a child, even when one or both of them already have children from previous relationships. In addition, it is part of life when they consider the risks and do not want to have children in such circumstances anymore, but it happened unexpectedly. Conclusion: Understanding reproductive needs and demands of these couples is an aid for qualification and improvement of care as a contribution to nursing care planning towards reproductive health of these couples.
\end{abstract}

Descriptors: Nursing Care; Sexual and Reproductive Rights; HIV; Pregnancy; Philosophy in Nursing.

\section{RESUMO}

Objetivo: Compreender o significado da gestação para casais heterossexuais diante da situação de sorodiscordância para o HIV com vistas à construção de possibilidades de cuidado fundadas na subjetividade. Método: Investigação fenomenológica, referencial teórico-filosófico-metodológico de Martin Heidegger. Foi desenvolvida em um Hospital Universitário no interior do Sul do Brasil entre setembro de 2013 a maio de 2014 por meio de entrevista fenomenológica, da qual participaram 11 casais. Resultados: Para os casais, a gestação faz parte do seu vivido quando têm vontade, desejam e querem ter o filho do casal, mesmo quando um ou ambos já têm filhos de relacionamentos anteriores. Também faz parte quando consideram os riscos e não querem mais ter filhos nessas circunstâncias, mas de forma inesperada isso aconteceu. Conclusão: Compreender as necessidades e demandas reprodutivas desses casais se mostra como subsídio para a qualificação e aprimoramento da atenção como contribuição para o planejamento dos cuidados de enfermagem à saúde reprodutiva desse casal.

Descritores: Cuidados de Enfermagem; Direitos Sexuais e Reprodutivos; HIV; Gravidez; Filosofia em Enfermagem.

\section{RESUMEN}

Objetivo: Comprender el significado del embarazo para las parejas heterosexuales serodiscordantes al VIH con el propósito de establecer cuidados basados en la subjetividad. Método: Estudio fenomenológico, de referencial teórico, filosófico, metodológico heideggeriano. Se empleó entrevista fenomenológica a once parejas participantes del estudio en el Hospital Universitario de una ciudad en la región Sur de Brasil en el periodo de septiembre de 2013 a mayo de 2014. Resultados: Para las parejas el embarazo forma parte de sus experiencias, ya sea porque desean tener hijos con el/la compañero/a, incluso si uno o ambos ya tienen hijos provenientes de relación anterior. Asimismo forma parte al considerar los riesgos y no desean tener más hijos en estas circunstancias, pero ocurre lo inesperado al quedarse embarazada. 
Conclusión: Comprender las necesidades y demandas reproductivas de estas parejas es importante para la calificación, el mejoramiento de los cuidados y la planificación de la asistencia ofrecida por el personal de enfermería a la salud reproductiva de estas personas.

Descriptores: Atención en Enfermería; Derechos Sexuales y Reproductivos; VIH; Embarazo; Filosofía en Enfermería.

\section{CORRESPONDING AUTHOR Tassiane Ferreira Langendorf E-mail: tassi.lang@gmail.com}

\section{INTRODUCTION}

The Brazilian response to epidemic of the virus that causes the Acquired Immunodeficiency Syndrome (AIDS) is based on the understanding that health is everybody's right, guaranteed by the Brazilian Unified Health System (SUS). This system allowed structuring a program of universal access to prevention, treatment and health care in all its dimensions ${ }^{(1)}$. In this perspective, as a result of therapeutic success, it was possible to achieve a considerable increase in life expectancy of people infected, and AIDS started to be classified as a chronic condition ${ }^{(2-3)}$. With these aspects, other needs come up for people living with the Human Immunodeficiency Virus (HIV) such as reproductive demands and the right to fatherhood and motherhood ${ }^{(4)}$.

Discussions involving reproductive topics and HIV can be considered from use of biotechnologies, through assisted human reproduction (AHR) and reproduction between heterosexual couples and homosexual couples resulting from new family arrangements. Such possibilities, associated with pregnancy on condition of one or both partners are infected with HIV, reflect that the reproductive health care of this couple, in particular, deserves a highlight ${ }^{(5)}$.

Regarding health care of people living with HIV (PLH), it is important to highlight practices of nursing care that must prioritize health-care promotion based on the universal access to a longitudinal and integral care ${ }^{(6)}$.

Specificity of HIV, lack of information and the need for qualification mobilize nurses to an active search for knowledge, aimed at strengthening of professional autonomy and quality of $\operatorname{care}^{(7)}$. Pregnancy with HIV diagnosis evidences relevance of the qualified nurse job beyond prevention of the virus vertical transmission, covering emotional and social aspects, seeking integrality ${ }^{(8)}$.

We must note that reproduction in a serodiscordant situation refers to couples in which only one partner is positive for HIV. This situation indicates challenges: in the social area, regarding the conjugal aspect, since the negative partner is exposed to HIV infection; and in the couple health-care area, considering the reproductive planning. Sometimes, these couples do not access health-care services for being afraid of being judged. Advising is a tool in the reproductive health care for these $\operatorname{couples}^{(9-12)}$, including the nursing care for their needs and reproductive demands.

Reproductive rights of PLH, including serodiscordant couples, are the same of people not infected with the virus. However, this topic is often silenced and neglected by health-care professionals ${ }^{(13)}$, who base their actions on moral values and stigmata. For an integral health care in the field of sexual and reproductive rights for serodiscordant couples, including discussion about the decision to have children is essential, since it implies the family characteristics ${ }^{(12)}$.
Health services are committed to meet demands of women living with HIV, their partners and families, especially over the puerperal pregnancy period ${ }^{(14)}$. Investments on professional qualification and health services accessibility reflect the importance of the relationship between health professionals and $\mathrm{PLH}$, which is able to bring benefits to therapeutic follow-up, prevention of diseases and quality of life $\mathrm{f}^{(15)}$.

In this panorama, the nursing consultation represents an effective intervention, evidencing the relevance of the relationship established in this action, which is able to promote health. To do so, professionals must reinforce individualities of patients through listening, which is a potentiality of health care for PLH, since it allows them to express their feelings and contributes to provide a care close to the need of each individual ${ }^{(16-17)}$. Such characteristics of performance of nurses are convergent for rethinking the intersubjectivity value in the relationship between who takes care and who is cared ${ }^{(18)}$.

With this study, from the meanings and senses unveiled, we seek to contribute to nursing care for reproductive health care of heterosexual serodiscordant couples for HIV. In addition, we aim to provide subsidy for nurses' action planning, whereas these professionals: are part of the health-care team that takes care of reproductive needs and demands of these couples; participate actively in amplified care over prenatal, delivery, puerperium and child care, as well as in development of educational activities, supported by scientific production ${ }^{(19)}$.

Given this scenario, this research aims to understand the meaning of pregnancy for heterosexual couples facing serodiscordant situation for HIV, aiming at implementing nursing care possibilities based on subjectivity.

\section{METHOD}

\section{Ethical aspects}

This research was developed according to the Resolution No. 466/12 of the National Health Council - Ministry of Health, which establishes guidelines and standards for research involving humans in Brazil(20). The project was approved by the Research Ethics Committee of the Federal University of Santa Maria.

\section{Theoretical-methodological framework}

Phenomenological qualitative research, aimed at unveiling of experiences and life of heterosexual serodiscordant couples for HIV infection diagnosis, who presented health demands aimed at prevention of HIV vertical transmission during the perinatal period. The research object guided the choice for the theoretical and philosophical framework by Martin Heidegger as well as the methodological framework by the same author $^{(21)}$. 


\section{Research location and participants}

The study scenario was a University Hospital located in a countryside city in the Southern region of Brazil; more specifically, the spaces of this hospital, where adults living with HIV are assisted according to their demands: adult outpatient clinic, prenatal and child care; Drug Distribution Unit and Center for Epidemiological Surveillance.

Regarding data source, possible participants in the study were defined according to the following inclusion criteria: heterosexual couples who considered themselves as a family, both partners with previous knowledge of seropositivity diagnosis of one of them by the time of the interview, and who experienced at least one pregnancy in the serodiscordant situation for HIV. The exclusion criterion was cases in which the man or the woman presented changes in the cognitive process of thought - however, using this criterion was not necessary.

As from the criteria and the couples who met them, eleven couples agreed to participate in the research and were interviewed. The partners were interviewed together, since this study aimed to investigate the couple experience with the pregnancy. Then, we understood that to access this phenomenon, it was necessary to listen to them together as a couple.

The number of participants was not predetermined, since the phenomenological study considers the possibility of reaching the essence of what shows up, established as the objective of the study, and not before, the quantity of interviews to be held. Thus, the field stage was developed along with the analysis, aimed at reflection about adequacy of the guiding question and empathetic questions that converge to the study path. This allowed pointing out sufficiency of meanings expressed in the speeches of couples, indicating the reach of the objective ${ }^{(22)}$.

\section{Data collection}

The researcher initially invited who was at the health service at the moment (couple, man or woman). Therefore, there was the need of who was invited to talk to his/her partner and, later on, the researcher got in contact for the second time to know whether the couple was interested in participating in the research. To do it so, a list with phone numbers of couples was made, in order to confirm interest and schedule the interview.

Whereas phenomenology seeks meanings and they are expressed by description intrinsic to the content of statements, the technique to obtain data was the phenomenological interview $^{(23)}$. We started this technique through the guiding question: How was the experience of having this child? In cases which couples did not deepen the serodiscordant situation in their statement, we asked the second question: How was the experience of having this child in a serodiscordant situation? The second question was necessary in five interviews.

The field stage was developed from September 2013 to May 2014. The interviews happened on date, time and place preferred by the couples, in institutional places or their residences. They were recorded with digital equipment and transcribed as they happened. Names of participants were replaced by the codes $\mathrm{W}$ for woman, $\mathrm{M}$ for man and $\mathrm{C}$ for child, when parents mentioned him or her in their speeches, followed by the numbers 1 to 11 (W1, M1, C1; W2, M2, C2; successively).

\section{Data Analysis}

We used the methodological framework of Martin Heidegger, which has two parts: 1) Vague Average Understanding and 2) Hermeneutics ${ }^{(21)}$. To develop the first part, readings and re-readings of the typed content of the interviews were carried out in order to identify and underline the essential structures, which constitute the structure of meaning of the phenomenon investigated. These structures are those couples express as life facts or significant experiences with the phenomenon studied, corresponding to the converging meanings, which respond to the purpose of the investigation.

After elucidation and gathering of meanings, the caput of the unit was elaborated -enunciation, header or title of the category a posteriori that constitutes the Unit of Meaning. Along with phenomenological speeches (detailed and textual descriptions of the set of meanings expressed in the couples' speeches), the Units of Meaning form the Vague Average Understanding. To elaborate the phenomenological speeches, the researcher attempted to rigorously follow the description of meanings by using words and expressions spoken by the couples.

Vague Average Understanding concerns the ontic dimension of the phenomenon, which can be perceived immediately ${ }^{(21)}$. It refers to the facts, to what exists and can be explained. Thus, the searched meanings at this methodical part can be understood as what is factual for the heterosexual serodiscordant couple for HIV during the pregnancy experience.

Hermeneutics, which is the second part, covers the interpretative analysis of the meanings apprehended that consisted of the units of meaning, seeking the possibility of unveiling phenomenal facets of the object under investigation. This is an interpretative movement that allows to go from the ontic, factual dimension, to the ontological, phenomenal dimension. In the ontological dimension, going towards the being, is where revealing facets of the phenomenon will be possible ${ }^{(21)}$.

\section{RESULTS}

Vague Average Understanding, first methodological part proposed by Martin Heidegger, allowed us to go towards the understanding of the meanings the couples themselves assigned to the pregnancy experience in the serodiscordant situation for HIV.

Therefore, the meanings were gathered and formed a unit of meaning.

\section{Unit of Meaning}

Heterosexual serodiscordant couples for HIV, regarding the pregnancy experience, expressed that getting pregnant was an expected fact, so it happened whether they wanted it or not.

The couples expressed that pregnancy is part of their life: considering different situations that involves it, such as wanting it, wishing to have the couple's child, even when one or both have children from previous relationships; when they take the risks into account and do not want to have children in such circumstances, but it happened unexpectedly.

W1 took all the initiatives, she said she wanted to have a baby [...]. At first, I didn't want to [...] But... we wanted it and it happened [...] But you have to want it, you have to feel like doing it. (M1) 
Now I'm gonna have a baby! The time is now! (W1)

When I lost the baby, I really wanted this baby, you know [...]. We already have other children, I have my own [...] we dreamed [...] we planned to have this child before all of this happened. I don't think there is something stronger than the desire of being a mother. Although I have my other children, we wanted to have our child. (W3)

We planned everything during nine months after she got pregnant, I mean, after she told me she was pregnant. (M3)

We found out I was pregnant after 3 months of pregnancy [...] I wanted to have a child, but not under these circumstances [...] then I entered in the false negative vibe [positive] and I got pregnant. (W6)

We were trying to get pregnant then, we started to have the idea to take it [the HIV test] [...] I never wanted to have children [...] We already knew my result was positive [...] but W6 really wanted this, so we ended up having this baby. (M6)

Actually, we didn't want another child, I have three kids and didn't want another one, and W10 has two. (M10)

I didn't want it either [to have more children]. (W10)

The pregnancy event surprised the couples. They did not see it coming, and when they found out, their partner were already pregnant and they were terrified since they could not imagine that this would happen. They did not believe what happened, because they did not want that, it was not the right time. When pregnancy attempts fail or when it does not come to the end, they do not give up. They take a break and pregnancy happens.

We didn't even expect it, you know? But when it happened, when W2 found out, she was already pregnant. (M2)

The thing is I was taking birth control pills, I didn't imagine I was going to get pregnant, you know? (W2)

We didn't plan it. (W4)

At first, we have planned it, but she ended up having preeclampsia, then after six months pregnant, she lost the baby. So we waited for a while and it happened. (M4)

Then we found out she got pregnant. (M5)

I found out about it after almost three months of pregnancy and I was terrified. (W5)

At first, we didn't plan it [...] it happened in a moment we wasn't expecting it [...] we wanted to have a child, we agreed about it [...] we had been trying and wasn't succeeding, then, she came... unexpectedly. (M8)

I tried to get pregnant for six years. I insisted and insisted so much, but I couldn't. Then one day, after I gave up, I took a test and found out I was pregnant. (W8)

Yes, it was a surprise. We didn't... We didn't expect it and we didn't want it, too [...]. We already considered a victory that [daughter's name] was fine, all right, [...] then thinking about going through it all over again... (M9)

I was scared, too. I'll be very honest, I didn't expect it and at this moment, I didn't want it [...] I checked the drugstore test and I was like: "Oh, I don't believe it," because I didn't want it, you know, it wasn't supposed to happen now. (W9)

Considering what they heard about HIV and serodiscordant situations, the men thought and used to say they could not have children and, because of it, they did not imagine their partners would get pregnant. Regarding what they know about the topic, at the beginning, they do not think about it and, when they do, the first thing they argue or claim is that they will not have children due to this situation.

At first, I didn't want it because I... actually I think the biggest prejudice has always come from me. (M1)

At the time, we don't think about this kind of thing, you know. [...] then I said: "So, [doctor's name], kids, no way, right? And he said: "Why not?" "How am I going to have a kid with him, right? It's impossible..." so the doctor said: "No, there's a possibility". (W1)

I didn't know she had it. If I knew it, of course I would avoid it [...] I'd be careful to not get her pregnant. (M7)

I got pregnant, you know, so I had to tell him [tell M7 about the HIV]. (W7)

Actually I told her [wife] when I met her: "Look, kids, no way, we can only do it with condoms." (M5)

I knew he had it [HIV], I just never thought I would get pregnant, that we'd have a kid together. (W5)

They prevent it a lot, the man wears a condom or the woman takes birth control pills. However, there is a flaw in the method and pregnancy happens. When they want to get pregnant, they do what it takes and look for resources to achieve it.

They think about the difficulties they will have to face, such as medicines that must be taken, taking the other children from one place to another and the stress at the hospital. They also think of the life risk the woman takes by getting pregnant... Anyway, the pregnancy happened.

We reached a point in which she asked, asked and asked for it, so I looked for medical help. (M1)

After we go it... ok, now let's try, let's see the possibilities [...] after a year, you know? (W1)

We were extremely careful [...] Over the sexual intercourse, the condom broke and she got pregnant. (M5)

Yes, we were very careful [...] But we didn't notice it [that the condom broke]. (W5)

Well, we didn't plan it, you know, so when W10 got pregnant, that was after two or three months, right, W10? [...] 
but it happened, what can you do, you know? [...] we have to spread the kids, like, he stays with his grandmother, the W10's kids stay with their grandmother. (M10)

Yes, I think for almost three months [when I discovered the pregnancy]. (W10)

Not this one, this was not planned. The others were planned, but not this one [...] because I was taking birth control pills and it was coming [the period] [...] he didn't want more [children]... You know, I didn't want more, too [...] the pills, you have to take them right [...] The children [...] Because he has a job, so I have to rush to do everything [...] So, it's difficult for me. (W11)

The problem was the pills [that is why she got pregnant] [...] A lot of blood came, we thought she was menstruating [...] [they did not want to have more children] even because of the risks, her risk of life, the problems, so everything affects it [...] Medicines, everything, you know, the stress, the hospital [...] The children, we have to rush with them out and about. (M11)

\section{DISCUSSION}

Hermeneutics or interpretation of the understanding of the participants, heterosexual serodiscordant couples for HIV, enlighten by Martin Heidegger's theoretical framework, determines we must clarify some concepts that supported the objective achievement in the study. This thinker developed an ontology, a study about the human being who lives in society in a given context and under certain conditions. His thought is expressed by hyphenated words with the purpose of etymological valuation to indicate the root and agglutinations.

Heidegger indicates the term entity to refer to people in their daily life. When referring to essence of people, he indicates the term being. The term -there indicates that one takes the place of protagonist of their own life events, experiences and relationships. In this study, the participants understood themselves as a couple, and Heideggerian Hermeneutics allowed us to perceive them as being-there-couple ${ }^{(21)}$.

The hyphenated composition of words being-in-the-world refers to the being who shares life events and experiences with the world, in a constant relationship with itself, with other people and things. When referring to the surrounding world, he points to what is closest to the being, characterized by the environment and immediate surroundings such as the workplace, the neighborhood and other coexistence spaces ${ }^{(21)}$.

In this world, the being develops a sight of what surrounds it, named circumspection, which gives it understanding of things and facts that will guide its action ${ }^{(21)}$. In this study, what surrounds the couple is the pregnancy in the serodiscordant situation for HIV. Thus, the circumspection of the pregnancy guided how the couple should concern with it to plan it. The term concern indicates habits, a predominant and prescribed way to be, in which the being repeats its actions or always does the same things in daily life.

Facing daily life events, the being establishes its field of action and exercises its movement freedom, going close to its interests and what it can understand, or moving away from things which it has no interest $\mathrm{in}^{(21)}$. For this movement, Heidegger indicates the term spatiality. In this study, the being-there-couple meant the reproduction experience as an event in which, wishing or not, pregnancy happened. It showed up as an approximation and moving away movement towards pregnancy, unveiling the way of being of spatiality ${ }^{(21)}$.

In their speeches, couples showed immediately their views about the seropositivity for HIV, pregnancy and serodiscordant situation topics. By reflecting about their life events and experiences with prejudice and discrimination, along with the information they have, they formed a thought, a circumspection.

From this view, couples showed themselves in the way of being of concern, that is, they concerned themselves with the desire to have children and the fear of that happening. Therefore, their circumspection guided this moving away and approximation movement from pregnancy in serodiscordant situation for HIV, which is by hand of the being in the surrounding world ${ }^{(21)}$.

Circumspection of couples expresses the understanding they have, which is influenced by information they receive or search. What we hear people saying can be understood in a median way, without ownership of what is spoken. What one talks about, because they heard people talking, brings with it an authoritarian character, stating that things are the way they are because that is how we heard of them ${ }^{(21)}$.

This understanding, which Heidegger called idle talk, is the thing about one talks that is repeated and passed on, increasing what is inappropriate and reinforcing the lack of solidity of what is said. Thus, the being-there have the possibility to understand everything without owning and understanding in advance the thing about one is talking ${ }^{(21)}$. Regarding the pregnancy experience, the being-there-couple talked about getting scared when they got pregnant and about not wanting the child due to HIV. Regarding this, they heard people saying they cannot have children because of the HIV and the serodiscordant situation, due to the risks for the negative partner and the child or, for this to happen, they need to look for professional help. The being-there-couple appears in the idle talk by repeating it authoritatively, as if they had understood the information that they could not have children.

The approximation or moving away movement towards pregnancy was established by the circumspection of the participants, that is, by what they know about HIV and the serodiscordant situation. In this interpretation, it showed up in the way of being of spatiality. Regarding moving away and guidance, these refer to the ontological dynamic of space constitution, highlighting that spatiality is not just a static position within an immobile space. The being is always concerned with a certain place and this must be understood as the approximation of what is by hand of the being in its surrounding world, from something already familiar, its circumspection ${ }^{(21)}$.

The being-there-couple expressed that pregnancy is part of their life, whether when they wished to have a child or, due to the risks, they did not want to have one. They consider these risks through their understanding of HIV and the serodiscordant situation. However, regardless of the desire of wanting to have children or not, the pregnancy happened.

The being-there-couple uses what is in their reach to meet their wishes. When they want to have children, they look for medical help, search for possibilities, use technological 
resources, try assisted reproduction and do not give up on their wish, even when they have lost another child in a previous pregnancy. When they do not want to have children, they use a male condom or birth control pills.

They concern themselves through their circumspection, bringing something to become close with the aim to obtain, have by hand, guided by the manual ability. This term indicates that, in the surrounding world, the being can use people and things as instruments. Every instrument carries in its essence utility and applicability characteristics, which indicate its being-for character ${ }^{(21)}$. Therefore, the being connects itself with the instrument and the manual ability in the field of action, without thinking about what it is doing, it just does what needs to be done in its daily life ${ }^{(21)}$.

Concerned, it shows itself in the manual ability by using the instruments it meets in its surrounding world, as male condoms and oral birth control pills to prevent pregnancy or the treatment routine for assisted human reproduction as a safe way to get pregnant. Guided by this circumspection of the impossibility of pregnancy in the serodiscordant situation, the being-there-couple concerns with pregnancy in their daily life to avoid it or to seek resources to make it happen.

Pregnancy is by hand of the being-there-couple in the surrounding world, because the being-there-couple can come close to it, making it happen or not. Although daily engaged and concerned with such handling, pregnancy happens unexpectedly. The beingthere-couple is surprised for not expecting to get pregnant or for having given up on it, but finds out about pregnancy. Whereas pregnancy happened, the being-there-couple is now responsible for experiencing it and its risks. Given this fact, there is nothing the being-there-couple can do to escape pregnancy. Thus, they are open for a "has to be" and surrender to the responsibility of "being what it is"(21): a serodiscordant couple for HIV who tried to get pregnant and a couple who avoided it, but got pregnant.

\section{Study limitations}

Challenges faced over the field stage to find people who met the inclusion criteria and could be invited to participate in the research outstand as a limitation of this research. Other factors are the inclusion criteria specificity and the deficit of registers on conjugality, serological situation of partners and reproductive issues. Given this, the prediction of a long time to develop this stage of the research was essential in the search for participant couples.

\section{Contributions to the field of nursing, health or public policy}

In the perspective of construction of nursing care based on subjectivity, this study uncovered the more proper being-able-tobe of the couple as a possibility, understood as: pregnancy in the serodiscordant situation with the couple having knowledge about what they will experience during pregnancy so it goes calmly, and minimizing vulnerability to infection of the negative partner and the baby in cases of vertical exposure to HIV. With that in mind, we state the importance of nursing care for reproductive health of serodiscordant heterosexual couples for HIV, both in the objective plan (biological, clinical) and in the subjective plan (social, existential), coming close to care integrality and enabling to guarantee the exercise of sexual and reproductive rights.

\section{FINAL CONSIDERATIONS}

From the understanding of meanings and interpretation of senses, this investigation unveiled the facets of how the beingthere-couple experienced pregnancy in the serodiscordant situation, allowing to understand reproductive needs and demands, of which we can highlight the need for a less prejudiced response from society and understanding of the subjective demand, which refers to reproductive planning for these couples.

This unveiling provided subsidies for qualification and improvement of health care as a contribution to direct and indirect nursing care of reproductive health of these couples, aiming to guarantee their sexual and reproductive rights. As indirect nursing care for reproductive health, we point out the need for deconstruction, through information based on scientific evidence, of truths based on myths, taboos, prejudice and discrimination, which, unveiled by the idle talk, defined the impossibility of pregnancy in the HIV context and, especially, in the serodiscordant situation.

Deconstructing this circumspection will reflect positively in a less prejudiced response, breaking with the idle talk and making possible for society and serodiscordant couples to understand that a safe pregnancy in the serodiscordant situation is possible. Therefore, the couple can assume their more proper being-able-to-be, which is being a serodiscordant couple for HIV who can reproduce and fully experience pregnancy, with possibility of dialogue in health consultations and understanding, concerning with the care that must be practiced and experienced not only during this time of their lives.

By assuming their more proper being-able-to-be, the serodiscordant being-there-couple for HIV will understand the need to search for sexual and reproductive health care in health services. With this in mind, we highlight the direct nursing care for reproductive health, which include at least nursing consultations aimed to these couples' reproductive planning, involving the clinical, social and cultural contexts and the existential dimension that refers to subjectivity. These aspects involve knowing how this planning can be done towards the achieving of the best results.

\section{REFERENCES}

1. Brasil. Ministério da Saúde. Recomendações de terapia antirretroviral para adultos vivendo com HIV/aids no Brasil. Versão Preliminar. Brasília: Ministério da Saúde, 2012.

2. Mendes EV. Health care networks. Ciênc Saúde Colet[Internet]. 2010 [cited 2016 May 20];15(5):2297-05. Available from: http:// www.scielo.br/pdf/csc/v15n5/v15n5a05.pdf 
3. Mendes EV. As redes de atenção à saúde. Brasília: Organização Pan-Americana da Saúde, 2011. 549 p.

4. Ventura M. Direitos Reprodutivos do Brasil. Fundo de População das Nações Unidas - UNFPA. 3.ed. Brasília - DF, 2009.

5. Langendorf TF, Padoin SMM, Vieira LB, Mutti CF. Gestantes que tem HIV/aids no contexto da transmissão vertical: visibilidade da produção cientifica nacional na área da saúde. Rev Pesq: Cuid Fundam[Internet]. 2011[cited 2016 May 20];3(3):2109-25. Available from: http://www.seer.unirio.br/index.php/cuidadofundamental/article/view/1358/pdf_416

6. Rocha GSA, Angelim RCM, Andrade ARL, Aquino JM, Abrão FMS, Costa AM. Nursing care of HIV-positive patients: considerations in the light of phenomenology. Rev Min Enferm[Internet]. 2015 [cited 2016 May 20];19(2):258-61. Available from: http://www. reme.org.br/artigo/detalhes/1020

7. Santos El, Gomes AMT. Vulnerability, empowerment and knowledge: nurses' memories and representations concerning care. Acta Paul Enferm[Internet]. 2013 [cited 2016 May 20];26(5):492-8. Available from: http://www.scielo.br/pdf/ape/v26n5/en_a14v26n5.pdf

8. Caldas MAG, Porangaba SCF, Melo ES, Gir E, Reis RK. Perception of the nursing team on pregnancy concerning infection caused by HIV. Rev Rene [Internet]. 2015[cited 2016 May 20];16(1):29-37. Available from: http://www.periodicos.ufc.br/index.php/rene/ article/viewFile/2660/2045

9. Gingelmaier A, Wiedenmann K, Sovric M, Mueller M, Kupka MS, Sonnenberg-Schwan U, et al. Consultations of HIV-infected women who wish to become pregnant. Arch Gynecol Obstet[Internet]. 2011 [cited 2016 May 26];283(4):893-98. Available from: http://link.springer.com/article/10.1007\%2Fs00404-010-1794-5

10. Erhabor $\mathrm{O}, \mathrm{Akani} \mathrm{Cl}$, Eyindah $\mathrm{CE}$. Reproductive health options among HIV-infected persons in the low-income Niger Delta of Nigeria. HIV/AIDS. Res Palliative Care[Internet]. 2012 [cited 2016 May 26]; 4:29-35. Available from: http://www.ncbi.nlm.nih. gov/pmc/articles/PMC3284261/

11. Matthews LT, Crankshaw T, Giddy J, Kaida A, Psaros C, Ware NC et al. Reproductive counseling by clinic healthcare workers in Durban, South Africa: perspectives from HIV-infected men and women reporting serodiscordant partners. Infect Dis Obstet Gynecol[Internet]. 2010 [cited 2016 May 26]; 2012:1-9. Available from: http://www.hindawi.com/journals/idog/2012/146348/

12. Reis RK, Neves LAS, Gir E. The desire to have children and family planning among hiv serodiscordant couples. Ciênc Cuid Saúde[Internet]. 2013 [cited 2016 May 26];12(2):210-18. Available from: http://www.periodicos.uem.br/ojs/index.php/ CiencCuidSaude/article/view/16393

13. Rahangdale L, Richardson A, Carda-Auten J, Adams R, Grodensky C. Provider Attitudes toward Discussing Fertility Intentions with HIV-Infected Women and Serodiscordant Couples in the USA. J AIDS Clin Res[Internet]. 2014 [cited 2016 May 26];5(6):01-13. Available from: http://www.ncbi.nlm.nih.gov/pmc/articles/PMC4160891/

14. Programa Conjunto das Nações Unidas sobre HIV/AIDS / VIH/SIDA (UNAIDS/ONUSIDA). Plano global para eliminar novas infecções por HIV em crianças até 2015 e manter suas mães vivas. Brasília: UNAIDS/ONUSIDA Brasil, 2011.

15. Costa T L, Oliveira DC, Formozo GA. The health sector in social representations of HIV/Aids and quality of life of seropositive people. Esc Anna Nery Rev Enferm[Internet]. 2015 Jul/Sep [cited 2016 May 20];19(3):475-83. Available from: http://www.scielo.br/pdf/ean/ v19n3/en_1414-8145-ean-19-03-0475.pdf

16. Bringel APV, Pereira MLD, Vidal ECF, Dantas GB. Experience of women diagnosed with HIV/Aids during pregnancy. Ciênc Cuid Saúde [Internet]. 2015 [cited 2016 May 20];14(2):1043-50. Available from: http://www.periodicos.uem.br/ojs/index.php/ CiencCuidSaude/article/view/22299

17. Tonera LCJ, Meirelles BHS. Potentialities and weaknesses in the care network of people with HIV/AIDS. Rev Bras Enferm[Internet]. 2015 [cited 2016 May 20];68(3):438-44. Available from: http://www.scielo.br/pdf/reben/v68n3/en_0034-7167-reben-68-03-0438.pdf

18. Langendorf TF, Padoin SMM, Paula CC, Souza IEO, Aldrighi JD. Prevention of vertical mother-to-child transmission of HIV: care and adhesion provided by couples. Rev Bras Enferm[Internet]. 2016 [cited 2016 May 31];69(2):275-81. Available from: http:// www.scielo.br/pdf/reben/v69n2/0034-7167-reben-69-02-0275.pdf

19. Barbosa TLA, Gomes LMX, Dias OV. Pre-natal consultation by nurses: client satisfaction among expectant mothers. Cogitare Enferm. [Internet]. 2011 [cited 2016 May 20]; 16(1):29-35. Available from: http://revistas.ufpr.br/cogitare/article/view/21108/13934

20. Brasil. Resolução 466/12 do Conselho Nacional de Saúde: dispõe sobre pesquisa envolvendo seres humanos. Comissão Nacional de Ética em Pesquisa (CONEP). 2012

21. Heidegger M. Ser e tempo. Tradução de Márcia Sá Cavalcante Schuback. 5ª ed. São Paulo (SP): Vozes, 2011.

22. Paula CC, Cabral IE, Souza IEO, Padoin SMM. [Analytical movement - Heideggerian hermeneutics: methodological possibility for nursing research]. Acta Paul Enferm[Internet]. 2012 [cited 2016 May 18];25(6):984-9. Available from: http://www.scielo.br/pdf/ ape/v25n6/v25n6a25.pdf Portuguese

23. Paula CC, Padoin SMM, Terra MG, Souza IEO, Cabral IE. [Driving modes of the interview in phenomenological research: experience report]. Rev Bras Enferm[Internet]. 2014 [cited 2016 May 18];67(3):468-72. Available from: http://www.scielo.br/pdf/ reben/v67n3/0034-7167-reben-67-03-0468.pdf Portuguese 